\title{
REUSE OF SAND, CRUSHED SUGARCANE AND PEANUT HULL-BASED SUBSTRATES FOR CHERRYTOMATO CULTIVATION
}

\author{
Carolina Fernandes ${ }^{1}$; José Eduardo Corá1*; Leila Trevizan Braz ${ }^{2}$ \\ ${ }^{1}$ UNESP/FCAV - Depto. de Solos e Adubos - Via de Acesso Prof. Paulo Donato Castellane, s/n - 14884-900 - \\ Jaboticabal, SP - Brasil. \\ ${ }^{2}$ UNESP/FCAV - Depto. de Produção Vegetal. \\ *Corresponding author <cora@fcav.unesp.br>
}

ABSTRACT: The reuse of substrates for more than one growing season is an alternative to reduce production costs. The objective of this work was to evaluate the yield and quality fruits of the cherry tomato (Lycopersicon esculentum) grown in reused substrates. The experimental design was a complete randomized block, with a factorial array of $7 \times 2$ (seven substrates and two growth periods), with four replications. The seven substrates consisted of different combinations of sand (S), crushed sugarcane (CS) and peanut hull (PH). The substrates used were: $\mathrm{S}_{1}=\mathrm{S} ; \mathrm{S}_{2}=[(2 / 3 \mathrm{~S})+(1 / 3 \mathrm{CS})] ; \mathrm{S}_{3}=[(2 / 3 \mathrm{~S})+$ $(1 / 3 \mathrm{PH})] ; \mathrm{S}_{4}=[(2 / 3 \mathrm{~S})+(1 / 6 \mathrm{CS})+(1 / 6 \mathrm{PH})] ; \mathrm{S}_{5}=[(1 / 2 \mathrm{~S})+(1 / 2 \mathrm{CS})] ; \mathrm{S}_{6}=[(1 / 2 \mathrm{~S})+(1 / 2 \mathrm{PH})]$ and $\mathrm{S}_{7}=$ $[(1 / 3 \mathrm{~S})+(1 / 3 \mathrm{CS})+(1 / 3 \mathrm{PH})]$. These substrates were tested as new (one growth season), and reused (two sequentially growth seasons). The cherry tomato average yield was $9.07 \mathrm{~kg} \mathrm{~m}^{-2}$ when growth on the new substrates, and $8.44 \mathrm{~kg} \mathrm{~m}^{-2}$ when growth on the reused ones. The fruit quality was not affected by the reutilization of the substrates. The average values were $6.5^{\circ} \mathrm{Brix}$ for total soluble solids; $0.6 \mathrm{~g}$ for citric acid per $100 \mathrm{~g}$ for total titratable acidity and 4.2 for $\mathrm{pH}$. A substrate consisting of equal parts of the three components can be recommended as a good growth medium for cherry tomato. All the substrates tested can be efficiently reused, at least once.

Key words: Lycopersicon esculentum, size of fruits, soilless growth

\section{REUTILIZAÇÃO DE SUBSTRATOS COMPOSTOS PORAREIA, BAGAÇO DE CANA-DE-AÇÚCAR E CASCA DE AMENDOIM NO CULTIVO DO TOMATEIRO DO GRUPO CEREJA}

\begin{abstract}
RESUMO: A reutilização de substratos por mais de um cultivo é uma alternativa para reduzir os custos de produção. Objetivou-se assim avaliar a produtividade e a qualidade dos frutos do tomateiro (Lycopersicon esculentum) do grupo cereja cultivado em substratos reutilizados. O delineamento experimental adotado foi o de blocos casualizados, com esquema fatorial $7 \times 2$ (sete substratos e duas utilizações dos substratos), em quatro repetições. Os substratos resultaram da combinação de diferentes proporções volumétricas de areia (A), bagaço de cana-de-açúcar (BC) e casca de amendoim (CA). Testou-se: $\mathrm{S}_{1}=\mathrm{A} ; \mathrm{S}_{2}=[(2 / 3 \mathrm{~A})+(1 / 3 \mathrm{BC})] ; \mathrm{S}_{3}=[(2 / 3 \mathrm{~A})+(1 / 3 \mathrm{CA})] ; \mathrm{S}_{4}=[(2 / 3 \mathrm{~A})+(1 / 6 \mathrm{BC})+(1 / 6 \mathrm{CA})]$; $S_{5}=[(1 / 2 A)+(1 / 2 B C)] ; S_{6}=[(1 / 2 A)+(1 / 2 C A)]$ e $S_{7}=[(1 / 3 A)+(1 / 3 B C)+(1 / 3 C A)]$. Os substratos foram utilizados em um cultivo (substratos novos $-S_{N}$ ) e dois cultivos (substratos reutilizados $-S_{R}$ ). A produtividade do tomateiro foi de $9,07 \mathrm{~kg} \mathrm{~m}^{-2}$, quando cultivado em $S_{\mathrm{N}}$, e de $8,44 \mathrm{~kg} \mathrm{~m}^{-2}$, quando cultivado em $S_{R}$. A qualidade dos frutos não foi influenciada pela reutilização dos substratos. Os valores médios foram de $6,5^{\circ}$ Brix para sólidos solúveis totais; $0,6 \mathrm{~g}$ de ácido cítrico por $100 \mathrm{~g}$ para acidez total titulável e 4,2 para o $\mathrm{pH}$. Para o cultivo do tomateiro do grupo cereja o substrato $\mathrm{S}_{7}$ pode ser recomendado, sendo viável reutilizar todos os substratos testados, pelo menos uma vez.

Palavras-chave: Lycopersicon esculentum, tamanho de frutos, cultivo sem solo
\end{abstract}

\section{INTRODUCTION}

In Brazil, growing vegetables in substrates has gained crescent interest among farmers, especially when the presence of soil pathogens makes greenhouse production unviable. Vegetable production in soiless substrates can be intensified even without crop rotation, which is a vital practice in soil growing vegetables. A substrate can be a mixture of several constituents. The use of sand as substrate for growing vegetables has shown positive results. Because of its very low ion exchange capacity, sand is considered an easy-to-use substrate (Abad et al., 2004). The major limitation for using sand as sub- 
strate its their difficult manipulation due to its high weight, especially when it is moist (Andriolo, 1996). Taking into consideration the availability and low cost, the use of agricultural, industrial and urban residues is vital to reduce production costs (Carrijo et al., 2004).

Besides technical knowledge substrate growing techniques require investing economic resources. The reuse of substrates for more than one growing season is an alternative to reduce production costs. Several studies have shown promising results for the reuse of substrates for two or more consecutive growths with no decrease in vegetable quality and/or yield. Baevre (1981) and Baevre \& Guttormsen (1984) showed that growing tomatoes in low humified Sphagnum peat gave satisfactory results when using the peat bags in three sucessive seasons without any sterilization.

Verlodt et al. (1985) studied the influence of reutilization of a substrate consisted of fresh Posidonia leaves and well decomposed cattle manure on the behavior of tomato crop during five years. They concluded that growth and yield were maximum in the third year of substrate utilization. Celikel \& Caglar (1999) showed that the highest yield of cucumber was obtained on a two-year used peat mixed with spent mushroom compost and volcanic tuff substrate (a ratio of 1:1:1) followed by threeyear used and unused peat. Reis et al. (2001) concluded that tomato yield were not different on the first or the second crop (reused substrate) both on grape marc compost or rockwool substrate. Besides, environment issues must be taken into account since the reuse of substrate waste reducing practice. On the other hand, some researchers have demonstrated that negative effects are likely to take place in reused substrates, e.g. disease dissemination, excessive nutrient concentration and nutritional unbalance. Baevre (1981) and Baevre \& Guttormsen (1984) observed an increase of phosphorus and boron form from one season to the next when a complete nutrient solution was used. Therefore, the authors deduced that the solution used for reused peat should have a lower content of phosphorus and boron in proportion to a solution used for one season growing media.

In this context, crushed sugarcane and peanut hull are agricultural residues available in the region of Jaboticabal (São Paulo State, Brazil), making then viable for substrates composition. This work was carried out to evaluate the yield and quality of cherry tomato fruits, grown in seven combinations of reused substrates of sand, crushed sugarcane and peanut hull.

\section{MATERIAL AND METHODS}

The experiment was conducted in a greenhouse

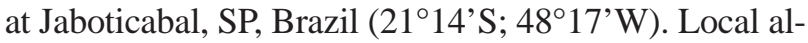
titude is $614 \mathrm{~m}$, and the climatic type (Köppen's classification) is Aw with transition to Cwa. The greenhouse was built with metal structure with arched ceiling measuring $3 \mathrm{~m}$ in height, $30 \mathrm{~m}$ in length, $8 \mathrm{~m}$ in width, and covered with transparent ultraviolet-blocking polyethylene film (150 micrometers thick). The sides were protected with black polypropylene screen providing $50 \%$ shading. The temperature and relative humidity inside the greenhouse were continously measured by a thermohydrograph, installed in a $1 \mathrm{~m}$ high wooden shelter, located at the center of the greenhouse. During plant growth the monthly averages for maximum temperature in July, August, September, October and November were $33,33,35,36$ and $38^{\circ} \mathrm{C}$, respectively, while the averages for minimum temperature were $11,11,13$, 14 and $16^{\circ} \mathrm{C}$, respectively. The averages for the daily maximum relative humidity were 98, 98, 96, 95 and $94 \%$, and for the daily minimum relative humidity 40 , 40, 39, 38 and 37\%, respectively.

The experiment was arranged in a randomized block design in a $7 \times 2$ factorial (seven substrates and two growth periods) with four replications. Samples comprised two pots containing one plant each. Plastic pots were brown, with $5 \mathrm{~L}$ capacity, $25 \mathrm{~cm}$ of upper diameter, $17 \mathrm{~cm}$ of bottom diameter, $18 \mathrm{~cm}$ in height and 8 holes in the bottom.

Substrates were made up of varying proportions of sand (S), crushed sugarcane (CS) and peanut hull (PH). The sand used is commercially known as "medium sand". Crushed sugarcane is the fiber-rich remain of sugarcane crushing. The peanut hull was ground and sifted in a $6 \times 18 \mathrm{~mm}^{2}$ sieve. The following substrates were tested: $\mathrm{S}_{1}=\mathrm{S} ; \mathrm{S}_{2}=[(2 / 3 \mathrm{~S})+$ $(1 / 3 \mathrm{CS})] ; \mathrm{S}_{3}=[(2 / 3 \mathrm{~S})+(1 / 3 \mathrm{PH})] ; \mathrm{S}_{4}=[(2 / 3 \mathrm{~S})+$ $(1 / 6 \mathrm{CS})+(1 / 6 \mathrm{PH})] ; \mathrm{S}_{5}=[(1 / 2 \mathrm{~S})+(1 / 2 \mathrm{CS})] ; \mathrm{S}_{6}=$ $[(1 / 2 \mathrm{~S})+(1 / 2 \mathrm{PH})]$ and $\mathrm{S}_{7}=[(1 / 3 \mathrm{~S})+(1 / 3 \mathrm{CS})+$ $(1 / 3 \mathrm{PH})]$, volume based (v:v:v). The substrates were tested as new $\left(\mathrm{S}_{\mathrm{N}}\right)$, which was used during one growth period, and reused $\left(S_{R}\right)$, which were used during two growth periods.

To obtain the reused substrate $\left(\mathrm{S}_{\mathrm{R}}\right)$, first a tomato crop was conducted from February through May on new substrates. Then, a second tomato crop was conducted from July through November, at the same conditions of the first one, using the same substrates, now called $S_{R}$. The treatments, new substrates $\left(S_{N}\right)$ and reused substrates $\left(\mathrm{S}_{\mathrm{R}}\right)$, were conducted in the same season, from July through November. The first tomato crop, from February through May, was done in order to obtain the reused substrate $\left(S_{R}\right)$. To get $S_{R}$ the first 
growth substrates were not removed from the pots. The shoots were removed by cutting them next to substrate surface, the roots being intact in the pots. A new seedling of 'Sindy' ( $F_{1}$ hybrid) cherry tomato with four leaves was transplanted into the reused pots. For the $\mathrm{S}_{\mathrm{N}}$ substrates, seedlings of 'Sindy' ( $\mathrm{F}_{1}$ hybrid) cherry tomato with four leaves were also transplanted into the pots with new substrate. The physical properties of each treatment was evaluated by Fernandes et al. (2006) and the easily available water content is on Table 1.

The one seedling pots were trained to two stems. The pots were spaced $1.0 \mathrm{~m} \times 0.5 \mathrm{~m}$ (2 plants $\left.\mathrm{m}^{-2}\right)$. Pruning and staking procedures were performed weekly. Topping was performed when plants reached $2 \mathrm{~m}$ height. The amount of water applied in irrigation was estimated to be the one necessary to visually identify drainage at the bottom of sand-filled pots. Little water leaching from the pots was observed. The low drainage from the pots was used as an indicative of the water distribution in the substrate into the pot. During cultivation, the amount of water used in irrigation increased with plant development stage. The water volume applied daily to each plant during the first 15 days after transplanting (DAT) was $0.78 \mathrm{~L}$, distributed equally in four irrigations times during a 24 hours period. At each stage, the daily water volumes provided were equally distributed in several irrigations times as following: from the $16^{\text {th }}$ to the $30^{\text {th }}$ DAT were applied $1.30 \mathrm{~L}$, distributed equally in 5 irrigations times a day; from the $31^{\text {st }}$ to the $45^{\text {th }}$ DAT, $1.82 \mathrm{~L}$ in 5 irrigations times; from the $46^{\text {th }}$ to the $60^{\text {th }}$ DAT, $2.34 \mathrm{~L}$ in 6 irrigations times; from the $61^{\text {st }}$ to the $75^{\text {th }} \mathrm{DAT}, 2.60 \mathrm{~L}$ in 6 irrigations times; from the $76^{\text {th }}$ to the $90^{\text {th }}$ DAT, 2.86 $\mathrm{L}$ in 7 irrigations times; from the $91^{\text {st }}$ to the $105^{\text {th }} \mathrm{DAT}$, $3.12 \mathrm{~L}$ in 7 irrigations times; and from the $106^{\text {th }}$ to the $135^{\text {th }}$ DAT, $3.38 \mathrm{~L}$ in 7 irrigations times. Trickle irrigation was performed with one sprinkler per pot, at a flow rate of $0.78 \mathrm{~L} \mathrm{~h}^{-1}$.

Table 1 - Easily available water content on each kind of substrate used for tomato growth.

\begin{tabular}{|c|c|c|}
\hline & $\begin{array}{c}\text { New } \\
\text { Substrates } \\
\left(\mathrm{S}_{\mathrm{N}}\right)\end{array}$ & $\begin{array}{c}\text { Reused } \\
\text { Substrates } \\
\quad\left(\mathrm{S}_{\mathrm{R}}\right)\end{array}$ \\
\hline & \multicolumn{2}{|c|}{ - } \\
\hline $\mathrm{S}_{1}(\mathrm{~S})$ & 24 & 23 \\
\hline $\mathrm{S}_{2}(2 / 3 \mathrm{~S}+1 / 3 \mathrm{CS})$ & 27 & 25 \\
\hline $\mathrm{S}_{3}(2 / 3 \mathrm{~S}+1 / 3 \mathrm{PH})$ & 24 & 23 \\
\hline $\mathrm{S}_{4}(2 / 3 \mathrm{~S}+1 / 6 \mathrm{CS}+1 / 6 \mathrm{PH})$ & 25 & 25 \\
\hline $\mathrm{S}_{5}(1 / 2 \mathrm{~S}+1 / 2 \mathrm{CS})$ & 24 & 23 \\
\hline $\mathrm{S}_{6}(1 / 2 \mathrm{~S}+1 / 2 \mathrm{PH})$ & 20 & 20 \\
\hline $\mathrm{S}_{7}(1 / 3 \mathrm{~S}+1 / 3 \mathrm{CS}+1 / 3 \mathrm{PH})$ & 12 & 16 \\
\hline
\end{tabular}

Fertilizers were provided in all irrigations, using the nutritive solution recommended by Moraes (1997) for tomato crops under the nutrient flow technique (NFT). Due to the high levels of boron and copper observed in tomato leaf tissues in the first crop (February to May), boron and copper concentration were reduced in the second crop (July to November), to $70 \%$ and $50 \%$ from the amounts used in the first growth, respectively. To make $1000 \mathrm{~L}$ of nutrient solution, $285 \mathrm{~g}$ of monoammonium phosphate; $600 \mathrm{~g}$ of magnesium sulfate; $1088 \mathrm{~g}$ of calcium nitrate; $423 \mathrm{~g}$ of potassium sulfate; $340 \mathrm{~g}$ of potassium chloride; $3 \mathrm{~g}$ of manganese sulfate; $0.45 \mathrm{~g}$ of zinc sulfate; $2.06 \mathrm{~g}$ of boric acid; $10 \mathrm{~g}$ of iron sulfate; $0.21 \mathrm{~g}$ of copper sulfate and $0.02 \mathrm{~g}$ of sodium molybdate were used. The total amount of each nutrient per plant applied during the growth period (135 days) was: $46 \mathrm{~g}$ of nitrogen; $14 \mathrm{~g}$ of phosphorus; $81 \mathrm{~g}$ of potassium; $48 \mathrm{~g}$ of calcium; $14 \mathrm{~g}$ of magnesium; $35 \mathrm{~g}$ of sulfur; $0.08 \mathrm{~g}$ of boron; $0.01 \mathrm{~g}$ of copper; $0.46 \mathrm{~g}$ of iron; $0.17 \mathrm{~g}$ of manganese; $0.02 \mathrm{~g}$ of zinc and $0.002 \mathrm{~g}$ of molybdenum.

For pest and disease control, sprayings were performed whenever necessary, following the rates and time lenghts recommended by the producer. The products used were systemic fungicides: Thiamethoxam $\left(15 \mathrm{~kg} \mathrm{ha}^{-1}\right)$, Azoxystrobin $\left(80 \mathrm{~g} \mathrm{ha}^{-1}\right)$, Benzimidazoles (70 $\mathrm{g} \mathrm{L}^{-1}$ of water); protector fungicides: Ditiocarbanate (3.0 $\left.\mathrm{kg} \mathrm{ha}^{-1}\right)$; systemic insecticide: Imidacloprid (0.5 $\mathrm{kg} \mathrm{ha}^{-1}$ ), Chlorfenapyr (50 mL $100 \mathrm{~L}^{-1}$ of water). Insecticides were used twice a week and fungicides once a week, according to those above mentioned different products and in a rotation scheme. Harvest began 78 days after transplanting, twice a week during 57 days.

Leaf sampling was carried out at first blow, which occurred 50 days after transplanting, according to Malavolta et al. (1997). Leafs were washed in deionized water, dried to constant weight in a forcedair oven at $60^{\circ} \mathrm{C}$, and ground for chemical analyses as recommended by Jones Jr. \& Case (1990). Nitrogen was determined by the Kjeldahl digestion, phosphorus and boron were determined by the colorimetric procedure, and potassium by the flame emission spectrometry procedure. Calcium, magnesium, sulfur, copper, iron, manganese and zinc were determined by the atomic absorption spectrometry.

Total soluble solids, total acidity, and $\mathrm{pH}$ were measured in mature fruits. Samples were consisted of twenty fruits. Total soluble solids and total acidity were performed following methods described by Moretti et al. (1998); $\mathrm{pH}$ was determined on undiluted tomato juice obtained by blending the fruits. All measurements were performed 106 days after transplanting, which occur in the middle of the harvest period. 
Fruits were classified as small, medium, large and giant, with masses ranging from $5 \mathrm{~g}$ and $10 \mathrm{~g} ; 10$ $\mathrm{g}$ and $15 \mathrm{~g} ; 15 \mathrm{~g}$ and $20 \mathrm{~g}$ and higher than $20 \mathrm{~g}$, respectively, as proposed by Fernandes et al. (2007). Fruits weight less than $5 \mathrm{~g}$ were considered non-marketable. Tomato yield was obtained for each size classes.

Data were submitted to the analysis of variance and means were compared by Tukey test at the $5 \%$ probability level.

\section{RESULTS AND DISCUSSION}

No significant interactions were observed between substrates and their reuse for any of the studied variables. Leaf nutrient levels, crop yield and fruit quality were similar among the seven substrates. The nutrient levels of leaf tissues 50 days after transplanting ranged from: 52.9 to $55.2(\mathrm{~m}=54.4) \mathrm{g} \mathrm{kg}^{-1}$ for $\mathrm{N} ; 5.6$ to $6.2(\mathrm{~m}=5.9) \mathrm{g} \mathrm{kg}^{-1}$ for P; 26.2 to 29.6 $(\mathrm{m}=27.9) \mathrm{g} \mathrm{kg}^{-1}$ for $\mathrm{K} ; 12.2$ to $13.7(\mathrm{~m}=12.6) \mathrm{g}$ $\mathrm{kg}^{-1}$ for Ca; 2.8 to $3.2(\mathrm{~m}=3.0) \mathrm{g} \mathrm{kg}^{-1}$ for $\mathrm{Mg} ; 7.7$ to $8.2(\mathrm{~m}=8.0) \mathrm{g} \mathrm{kg}^{-1}$ for $\mathrm{S}$; 58 to $63(\mathrm{~m}=61) \mathrm{mg} \mathrm{kg}^{-1}$ for $\mathrm{B}$; 644 to $762(\mathrm{~m}=689) \mathrm{mg} \mathrm{kg}^{-1}$ for $\mathrm{Cu}$; 344 to $628(\mathrm{~m}=465) \mathrm{mg} \mathrm{kg}^{-1}$ for Fe; 156 to $236(\mathrm{~m}=194)$ $\mathrm{mg} \mathrm{kg}{ }^{-1}$ for $\mathrm{Mn}$; and 34 to $40(\mathrm{~m}=37) \mathrm{mg} \mathrm{kg}^{-1}$ for $\mathrm{Zn}$. The yield of the four size classes ranged from: 0.71 to $1.29(\mathrm{~m}=1.13) \mathrm{kg} \mathrm{m}^{-2}$ for small fruits; 3.68 to 4.34 ( $\mathrm{m}=3.92) \mathrm{kg} \mathrm{m}^{-2}$ for medium fruits; 2.64 to 3.35 (m $=3.18) \mathrm{kg} \mathrm{m}^{-2}$ for large fruits; and 0.45 to $1.10(\mathrm{~m}=$ $0.89) \mathrm{kg} \mathrm{m}^{-2}$ for giant fruits. The quality traits ranged from: 6.3 to $6.7(\mathrm{~m}=6.5){ }^{\circ} \mathrm{Brix}$ for total soluble solids; 0.6 to $0.7(\mathrm{~m}=0.6) \mathrm{g}$ of citric acid per $100 \mathrm{~g}$ for total titrable acidity; and 4.2 to $4.3(\mathrm{~m}=4.2)$ for $\mathrm{pH}$.

The quality results obtained in the present study were in accordance with other authors. González et al. (2004) showed results of many authors for different cherry tomato cultivars, which ranged from 5.1 to $8.0^{\circ}$ Brix for total soluble solids, 0.4 to $0.8 \mathrm{~g}$ of citric acid per $100 \mathrm{~g}$ for total titrable acidity, and 3.8 to 6.6 for $\mathrm{pH}$.

Considering the availability and low cost of crushed sugarcane (CS) and peanut hull (PH) in the
Jaboticabal region and the difficulty of sand (S) manipulation, we recommend the substrate $S_{7}[(1 / 3 \mathrm{~S})$ $+(1 / 3 \mathrm{CS})+(1 / 3 \mathrm{PH})]$. Among all substrates, the $\mathrm{S}_{7}$ is the highest in organic components and lowest in sand. Leaf nutrient levels 50 days after transplanting (Table 2), and tomato yield (Table 3) were influenced by the reuse of substrates, while fruit quality (Table 4) was similar between the first and the second growth, i.e. when substrates were new and reused.

Leaf tissues of plants on reused substrates $\left(\mathrm{S}_{\mathrm{R}}\right)$ showed lower levels of phosphorus and sulfur and higher levels of magnesium, iron, manganese and zinc, when compared with plants grown on new substrates $\left(\mathrm{S}_{\mathrm{N}}\right)$ (Table 2). However, no nutritional disorder symptoms was observed on the plants. Nutrient levels were measured 50 days after transplanting (Table 2), and compared with those levels considered adequate by Malavolta et al. (1997) $(\mathrm{N}=30, \mathrm{P}=3.5, \mathrm{~K}=40$, Ca $=14-18, \mathrm{Mg}=4, \mathrm{~S}=3$, in $\mathrm{g} \mathrm{kg}^{-1} ; \mathrm{B}=50-70, \mathrm{Cu}$ $=10-15, \mathrm{Fe}=500-700, \mathrm{Mn}=250-400, \mathrm{Zn}=60$ - 70, in $\mathrm{mg} \mathrm{kg}^{-1}$ ). According to these parameters the nitrogen, phosphorus and sulfur levels were high; the potassium and zinc were low; and copper was very high. Other nutrients had adequate levels. These numeric levels are generalized and can be influenced by root conditions, climate and variety (Malavolta et al., 1997).

The high level of $\mathrm{Cu}$ in the leaves probably was not due to the kind of substrate nor the pest and disease control products, because the components of the substrates did not present high levels of $\mathrm{Cu}$ (sand = $0.02 \mathrm{mg} \mathrm{L}^{-1}$, crushed sugarcane $=0.03 \mathrm{mg} \mathrm{L}^{-1}$, peanut hull $=0.21 \mathrm{mg} \mathrm{L}^{-1}$ ), neither the fungicides or insecticides had $\mathrm{Cu}$ in their composition. Therefore, the high level of copper in tomato leaves indicates that the nutrient solution concentration used in this work was not adequate for the cherry tomato cultivar 'Sindy'. On the other hand, the reduction of boron concentration was satisfactory, since this nutrient levels were found to be adequate. Therefore more studies about nutrient solution concentration for growing cherry tomato in substrates should be done.

Table 2 - Nutrient levels of nitrogen (N), phosphorus (P), potassium (K), calcium (Ca), magnesium (Mg), sulfur (S), boron (B), copper $(\mathrm{Cu})$, iron $(\mathrm{Fe})$, manganese $(\mathrm{Mn})$ and zinc $(\mathrm{Zn})$ in cherry tomato 'Sindy' leaves, conducted in new $\left(\mathrm{S}_{\mathrm{N}}\right)$ and reused substrates $\left(\mathrm{S}_{\mathrm{R}}\right)$ in the $50^{\text {th }}$ day after transplanting.

\begin{tabular}{|c|c|c|c|c|c|c|c|c|c|c|c|}
\hline & $\mathrm{N}$ & $\mathrm{P}$ & $\mathrm{K}$ & $\mathrm{Ca}$ & $\mathrm{Mg}$ & $\mathrm{S}$ & B & $\mathrm{Cu}$ & $\mathrm{Fe}$ & $\mathrm{Mn}$ & $\mathrm{Zn}$ \\
\hline & - & - & g & $g^{-1}-\ldots$ & 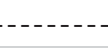 & ----- & \multicolumn{5}{|c|}{ - $\mathrm{mg} \mathrm{kg}^{-1} \ldots \ldots \ldots$} \\
\hline $\mathrm{S}_{\mathrm{N}}$ & 54.6 a & $6.0 \mathrm{a}$ & $27.4 \mathrm{a}$ & $12.9 \mathrm{a}$ & $2.8 \mathrm{~b}$ & $8.3 \mathrm{a}$ & $61 \mathrm{a}$ & 673 a & $261 \mathrm{~b}$ & $137 \mathrm{~b}$ & $34 \mathrm{~b}$ \\
\hline$S_{R}$ & $54.1 \mathrm{a}$ & $5.7 \mathrm{~b}$ & $27.8 \mathrm{a}$ & $13.1 \mathrm{a}$ & $3.1 \mathrm{a}$ & $7.5 \mathrm{~b}$ & $60 \mathrm{a}$ & 743 a & 623 a & $250 \mathrm{a}$ & 39 a \\
\hline $\mathrm{CV}(\%)$ & 3.7 & 5.0 & 7.1 & 11.9 & 11.1 & 7.2 & 7.2 & 18.6 & 46.7 & 40.4 & 13.6 \\
\hline
\end{tabular}

Means followed by different letters in the columns differ according to Tukey's test $(\alpha=0.05)$ and according to $\mathrm{F}$ test $(P<0.01)$. 
Table 3 - Tomato yield according to each size fruit classes - small (from $5 \mathrm{~g}$ to $10 \mathrm{~g}$ ), medium (from $10 \mathrm{~g}$ to $15 \mathrm{~g}$ ), large (from $15 \mathrm{~g}$ to $20 \mathrm{~g}$ ) and giant (higher than $20 \mathrm{~g}$ ), and total fruit yield for 'Sindy' cherry tomato, grown in new $\left(\mathrm{S}_{N}\right)$ and reused substrates $\left(\mathrm{S}_{\mathrm{R}}\right)$.

\begin{tabular}{lccccc}
\hline & Small & Medium & Large & Giant & Total \\
\hline & $-\ldots .90 \mathrm{a}$ & $3.86 \mathrm{a}$ & $3.29 \mathrm{a}$ & $1.02 \mathrm{a}$ & $9.07 \mathrm{a}$ \\
$\mathrm{S}_{\mathrm{N}}$ & $0.9 \mathrm{a} \mathrm{m}^{-2}$ & $\ldots .11 \mathrm{a}$ & $2.68 \mathrm{~b}$ & $0.55 \mathrm{~b}$ & $8.44 \mathrm{~b}$ \\
$\mathrm{~S}_{\mathrm{R}}$ & $1.10 \mathrm{a}$ & 4.11 & & \\
$\mathrm{CV}(\%)$ & 46.6 & 22.9 & 28.1 & 50.3 & 10.7 \\
\hline
\end{tabular}

Means followed by different letters in the columns differ according to Tukey's test $(\alpha=0.05)$ and according to F test $(P<0.01)$.

Table 4 - Total soluble solids, total titrable acidity and $\mathrm{pH}$ of 'Sindy' cherry tomato, grown in new $\left(\mathrm{S}_{\mathrm{N}}\right)$ and reused substrates $\left(\mathrm{S}_{\mathrm{R}}\right)$.

\begin{tabular}{lccc}
\hline & Soluble solids & Titrable acidity & $\mathrm{pH}$ \\
\hline & ${ }^{\circ}$ Brix & $\begin{array}{c}\text { Citric acid } \\
\left(\mathrm{g} 100^{-1} \mathrm{~g}\right)\end{array}$ \\
$\mathrm{S}_{\mathrm{N}}$ & $6.4 \mathrm{a}$ & $0.6 \mathrm{a}$ & $4.2 \mathrm{a}$ \\
$\mathrm{S}_{\mathrm{R}}$ & $6.6 \mathrm{a}$ & $0.6 \mathrm{a}$ & $4.2 \mathrm{a}$ \\
\hline $\mathrm{CV}(\%)$ & 4.8 & 8.2 & 0.6 \\
\hline
\end{tabular}

Means followed by different letters in the columns differ according to Tukey's test $(\alpha=0.05)$ and according to F test $(P<0.01)$.

Reusing a turf substrate for tomato growing increased phosphorus and boron levels in the leaves without nutritional unbalance (Baevre, 1981). Baevre \& Guttormsen (1984) also studied turf substrates and observed that magnesium and boron levels in the leaves increased when plants were grown in reused substrates but no toxicity symptom was observed. Verlodt et al. (1985) tested the reuse of plant residue substrates and observed that nitrogen, phosphorus, potassium, calcium and magnesium levels in tomato leaves were not affected by five growth periods. However, an accumulation of zinc, copper and manganese was observed in leaves during the fourth growth.

Independently of the kind of substrates, the use of new substrates $\left(\mathrm{S}_{\mathrm{N}}\right)$ resulted in higher production of large and giant fruits, and consequently in higher total fruit yield $\left(9.07 \mathrm{~kg} \mathrm{~m}^{-2}\right)$ when compared to reused substrates $\left(\mathrm{S}_{\mathrm{R}}\right)\left(8.44 \mathrm{~kg} \mathrm{~m}^{-2}\right)$ (Table 3). Other researchers observed that the reuse of substrates did not affect yield. The reuse of substrates, with no sterilization, for two (Reis et al., 2001), three (Baevre, 1981) or four growths (Baevre \& Guttormsen, 1984) did not decrease tomato yield. The averages of tomato yield were: $12.7 \mathrm{~kg} \mathrm{~m}^{-2}$ of tomato 'Sinatra' (Reis et al., 2001) and $23.2 \mathrm{~kg} \mathrm{~m}^{-2}$ of tomato 'Virosa' (Baevre \& Guttormsen, 1984).
The quality of cherry tomatoes produced in the $\mathrm{S}_{\mathrm{N}}$ or $\mathrm{S}_{\mathrm{R}}$ was not different (Table 4). Charlo et al. (2004) grew the cherry tomato cultivar 'Sindy' at the same time as the present work, but on soil in a greenhouse, which was located side by side of the one where the present work was carried out. The Charlo's tomato yield was $8 \mathrm{~kg} \mathrm{~m}^{-2}$ and the total soluble solids were $4.1^{\circ} \mathrm{Brix}$. As it can be seen, the yield and quality tomato obtained in the present study were higher than the ones of Charlo's study, which was conducted in similar environment conditionals except by the soil material, which is the main way used by local farmers.

Even though, lower yields were obtained here on reused substrates $\left(8.44 \mathrm{~kg} \mathrm{~m}^{-2}\right.$, soluble solids $=8.0$ ${ }^{\circ}$ Brix) they still were higher than the yields obtained by Charlo et al. (2004). Therefore, this is an indication that the reuse of substrates is an economical possibility for growing tomato.

As conclusion, the substrate $\mathrm{S}_{7}$ consisting of equal parts of sand, crushed sugarcane and peanut hull can be recommended as growth medium for cherry tomato. All the substrates tested can be reused at least once.

\section{ACKNOWLEDGEMENTS}

To CNPq for granting a Scholarship to C. Fernandes.

\section{REFERENCES}

ABAD, M.B.; NOGUERA, P.M.; CARRIÓN, C.B. Los sustratos en los cultivos sin suelo. In: URRESTARAZU, M.G. (Ed.) Tratado de cultivo sin suelo. Madrid: Mundi-Prensa, 2004. p.113158.

ANDRIOLO, J.L. O cultivo de plantas com fertirrigação. Santa Maria: UFSM, 1996. 47p.

BAEVRE, O.A. Chemical and physical properties of re-used peat for tomato. Acta Horticulturae, n.126, p.45-50, 1981.

BAEVRE, O.A.; GUTTORMSEN, G. Reuse of peat bags for tomatoes and cucumbers. Plant and Soil, v.77, p.207-214, 1984.

CARRIJO, O.A.; VIDAL, M.C.; REIS, N.V.B.; SOUZA, R.B.; MAKISHIMA, N. Produtividade do tomateiro em diferentes substratos e modelos de casas de vegetação. Horticultura Brasileira, v.22, p.5-9, 2004.

CELIKEL, G.; CAGLAR, G. The effects of re-using different substrates on the yield and earliness of cucumber on autumn growing period. Acta Horticulturae, n.492, p. 259-264, 1999.

CHARLO, H.C.O.; CASTOLDI, R.; CONTI, P.L.; FARIA, A.U.; BRAZ, L.T.; FERNANDES, C. Desempenho de mini tomate em casa de vegetação, conduzido em diferentes espaçamentos e poda. Horticultura Brasileira, v.22, 2004. Suplemento 2. 1 CD-ROM.

FERNANDES, C.; CORÁ, J.E.; BRAZ, L.T. Alterações nas propriedades físicas de substratos para cultivo de tomate cereja, em função de sua reutilização. Horticultura Brasileira, v.24, p.94-98, 2006.

FERNANDES, C.; CORÁ, J.E.; BRAZ, L.T. Classificação de tomatecereja em função do tamanho e peso dos frutos. Horticultura Brasileira, v.25, p.275-278, 2007. 
GONZÁLEZ, A.C.; SALAS, M.C.S.; URRESTARAZU, M.G. Producción y calidad en el cultivo de tomate cherry. In: URRESTARAZU, M.G. (Ed.) Tratado de cultivo sin suelo. Madrid: Mundi-Prensa, 2004. p.703-748.

JONES JR., J.B.; CASE, V.W. Sampling, handling, and analyzing plant tissue samples. In: WESTERMAN, R.L. (Ed.). Soil testing and plant analysis. 3.ed. Madison: Soil Science Society of America, 1990. p.389-427. (SSSA Book Series, 3).

MALAVOLTA, E.; VITTI, G.C.; OLIVEIRA, S.A. Avaliação do estado nutricional das plantas: princípios e aplicações. 2.ed. Piracicaba: POTAFOS, 1997. 319p.

MORAES, C.A.G. Hidroponia: como cultivar tomates em sistema NFT (técnica do fluxo laminar de nutrientes). Jundiaí: DISQ Editora, 1997. 141p.

MORETTI, C.L.; SARGENT, S.A.; HUBER, D.J.; CALBO, A.G.; PUSCHMANN, R. Chemical composition and physical properties of pericarp, locule, and placental tissues of tomatoes with internal bruising. Journal of the American Society for Horticultural Science, v.123, p.656-660, 1998.
REIS, M.; INÁCIO, H.; ROSA, A.; CAÇO, J.; MONTEIRO, A. Grape marc compost as an alternative growing media for greenhouse tomato. Acta Horticulturae, n.554, p.75-81, 2001.

VERLODT, H.; ZOUAOUI, M.; SAIDANE, A.; WAELE, N.; HARBAOUI, Y. Influence of reutilization during five years on the physical and chemical properties of a Posidonia oceanica (L.) Del. substrate and on the behavior of a tomate crop. Acta Horticulturae, n.172, p.157-173, 1985.

Received March 17, 2006

Accepted September 04, 2007 